\begin{tabular}{lr}
\hline PRACE NAUKOWE UNIWERSYTETU EKONOMICZNEGO WE WROCEAWIU \\
RESEARCH PAPERS OF WROCLAW UNIVERSITY OF ECONOMICS & nr 498・2017 \\
\hline Nauki ekonomiczne w XXI wieku - wyzwania, dylematy, perspektywy & ISSN 1899-3192 \\
Międzynarodowe stosunki gospodarcze & e-ISSN 2392-0041
\end{tabular}

\title{
Anna Janiszewska
}

Uniwersytet Łódzki

e-mail: anna.janiszewska@geo.uni.lodz.pl

\section{POLITYKA IMIGRACYJNA AUSTRALII}

\section{AUSTRALIAN IMMIGRATION POLICY}

DOI: $10.15611 /$ pn.2017.498.10

JEL Classification: J11, J15, J18

\begin{abstract}
Streszczenie: W artykule podjęta została problematyka związana z polityką imigracyjną Australii, a szczególnie aspekty tej polityki, które wpływają na kształtowanie się potencjału ludnościowego i jego struktury. Przedstawiono ewolucję poglądów, rozwiązań prawnych i działań Związku Australijskiego, które doprowadziły do zarzucenia polityki White Australia i wprowadzenia polityki wielokulturowości. Celem artykułu było także określenie wpływu ruchu migracyjnego na rozmiary zasobów ludnościowych Australii.
\end{abstract}

Słowa kluczowe: polityka imigracyjna, ruch migracyjny, ludność, White Australia, multikulturalizm, Związek Australijski.

Summary: The study addresses issues related to Australia's immigration policy, and in particular, aspects of this policy that affect the development of population potential and its structure. This article presents the evolution of the Australian Government's views, their legal solutions and actions which led to the abrogation of White Australia's policy and the introduction of multiculturalism. The purpose of this article was also to determine the impact of migration on population size in Australia.

Keywords: immigration policy, migration movement, population, White Australia, multiculturalism, Commonwealth of Australia.

\section{Wstęp}

Australia to kraj prawdziwie wielokulturowy - co czwarty jej mieszkaniec urodził się za granicą, a co drugi ma przynajmniej jednego rodzica imigranta. Jednocześnie Australia słynie z tego, że reprezentanci innych kultur dobrze się w tym kraju integrują. Na dzisiejszy obraz zróżnicowanej struktury etnicznej mieszkańców Związku Australijskiego wpłynęły różne czynniki, w dużym stopniu były to decyzje administracyjne władz, dotyczące prowadzonej polityki odnoszącej się do potencjału ludnościowego i jego struktury narodowościowej. 
Australijska wielokulturowość charakteryzuje się pojmowaniem kultury w ujęciu dynamicznym. Kultura podlega ciągłym zmianom pod wpływem przyjmowania elementów kultur przybywających imigrantów. Tak pojęta kultura ewoluuje i nie jest zbiorem niezmiennych wartości i tradycji. Elementem, który wyznacza granice zmiany, jest przestrzeganie prawa oraz zasad liberalnej demokracji i tolerancji, czyli wartości charakterystycznych dla cywilizacji Zachodu. W ramach australijskiej koncepcji wielokulturowości nie zanegowano wszystkich wartości zachodnich, w tym wartości kręgu anglosaskiego. Najlepszym na to dowodem jest fakt, że wyróżnikiem australijskiej tożsamości jest nadal umiejętność posługiwania się językiem angielskim, będącym jedynym językiem urzędowym Australii. Jego znajomość dla celów edukacyjnych bądź zawodowych musi zostać potwierdzona standaryzowanymi w skali międzynarodowej metodami [Krakowiak 2012].

W opracowaniu przedstawiono uwarunkowania rozwoju ludnościowego Australii ze szczególnym uwzględnieniem ruchów migracyjnych, mających zarówno w przeszłości, jak i obecnie znaczący udział w kształtowaniu potencjału demograficznego kraju. Pozwoliło to na określenie wpływu polityki imigracyjnej na rozmiary zasobów ludnościowych i jego struktury.

\section{Modele polityki migracyjnej}

Polityka ludnościowa to część polityki społecznej, ukierunkowanej na osiągnięcie optimum ludnościowego. Owo optimum może być utożsamione z taką ludnością, dla której liczba, struktura i rozmieszczenie są najkorzystniejsze z pewnego punktu widzenia. Szerokie ujęcie polityki ludnościowej (sensu largo) to każde działanie władz publicznych ukierunkowane na zwiększenie stopnia zaspokojenia potrzeb społecznych wyłaniających się z przemian demograficznych (polityka bierna, reaktywna). Polityka ludnościowa sensu stricto (tj. wąsko definiowana) to działania władz publicznych mające na celu kształtowanie przebiegu procesów ludnościowych (polityka czynna, kształtująca). Jako subpolityki polityki ludnościowej należy wyróżnić: rodzinną, zdrowotną, migracyjną. Politykę migracyjną należy traktować jako działania ukierunkowane na migracje zewnętrzne (tj. polityka imigracyjna i emigracyjna) i te mające na celu oddziaływanie na skłonność do przemieszczeń w ramach kraju. Zarówno polityka imigracyjna, jak i emigracyjna mogą mieć charakter uniwersalny lub selektywny. Kryterium, które je różnicuje, to jest sposób traktowania pewnych grup społecznych przez podmiot prowadzący politykę [Holzer 2003].

Analiza obecnie zachodzących przemian w zakresie doktryn i polityk migracyjnych stosowanych przez poszczególne państwa świata pozwala na wyróżnienie pięciu modeli polityki migracyjnej (rys. 1). 


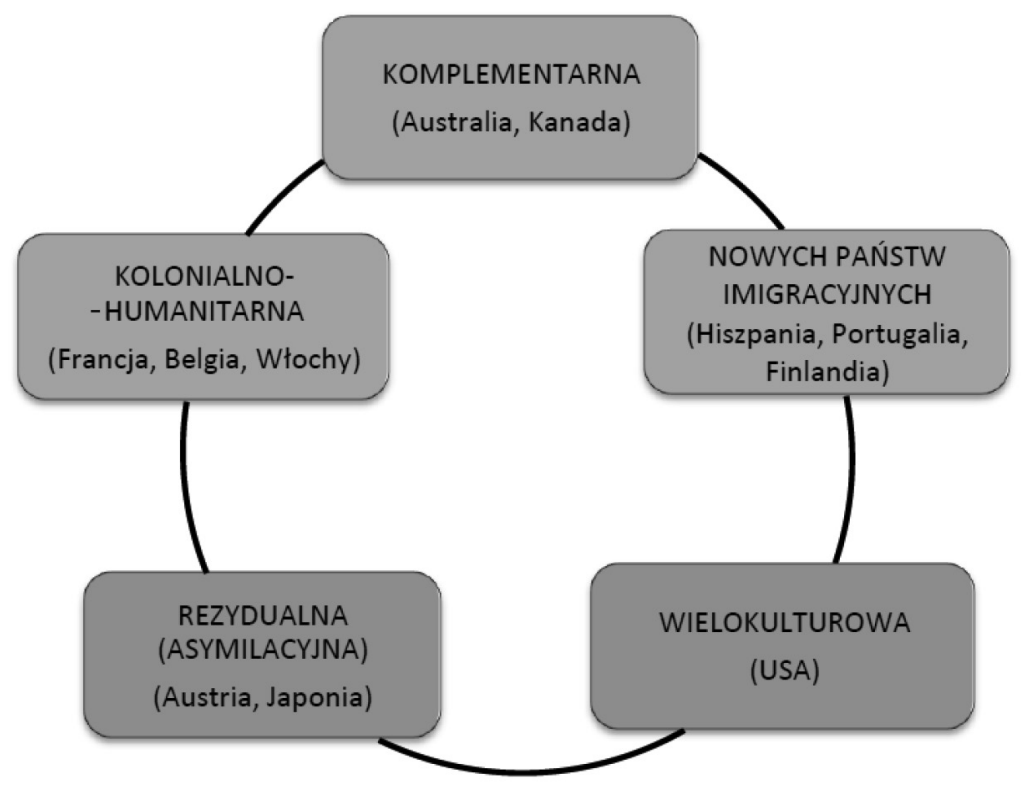

Rys. 1. Modele polityki migracyjnej

Źródło: [Kaczmarczyk, Okólski 2008].

\section{Uwarunkowania rozwoju ludnościowego Australii}

Kolonizacja Australii rozpoczęła się w 1770 r. i przebiegała w kilku etapach:

- Rozpoczęła się przymusową migracją zesłańców z Wysp Brytyjskich (1788-1830), do Australii przybyło 77 tys. przesiedleńców, z czego 63 tys. stanowili więźniowie. W początkowym etapie osadnictwa ludność osiedlała się na południowo-wschodnich wybrzeżach morskich (koniec deportacji 1868 r.).

- W drugim etapie (od lat 30. do 50. XIX w.) mamy do czynienia z kolonizacją systematyczną, prowadzoną nie tylko przez mieszkańców z Wielkiej Brytanii i innych państw europejskich, ale także imigrantów ze Stanów Zjednoczonych, Azji i Ameryki Łacińskiej - osadnictwo na południowo-zachodnich wybrzeżach Australii.

- Trzeci etap, trwający od poł. XIX do poł. XX w., to okres restrykcyjnej polityki migracyjnej, nazywanej polityką białej Australii - osadnictwo postępujące w głąb kraju.

- Ostatni etap, trwający od lat 60. ubiegłego wieku, to masowa imigracja do Australii [Janiszewska, Klima 2009; Sale, Wilson 1984].

W rozwoju ludnościowym migracja odgrywała i nadał odgrywa znacząca rolę:

- Udział migracji zagranicznej netto w przyroście rzeczywistym był różny w zależności od sytuacji politycznej i gospodarczej. Mniejsze udziały migracji 
w wielkości przyrostu rzeczywistego dotyczyły np. restrykcyjnych rozwiązań prawnych czy kryzysu gospodarczego. W pierwszej dekadzie XX w. udział migracji w przyroście rzeczywistym wynosił blisko $60 \%$ (rys. 2).

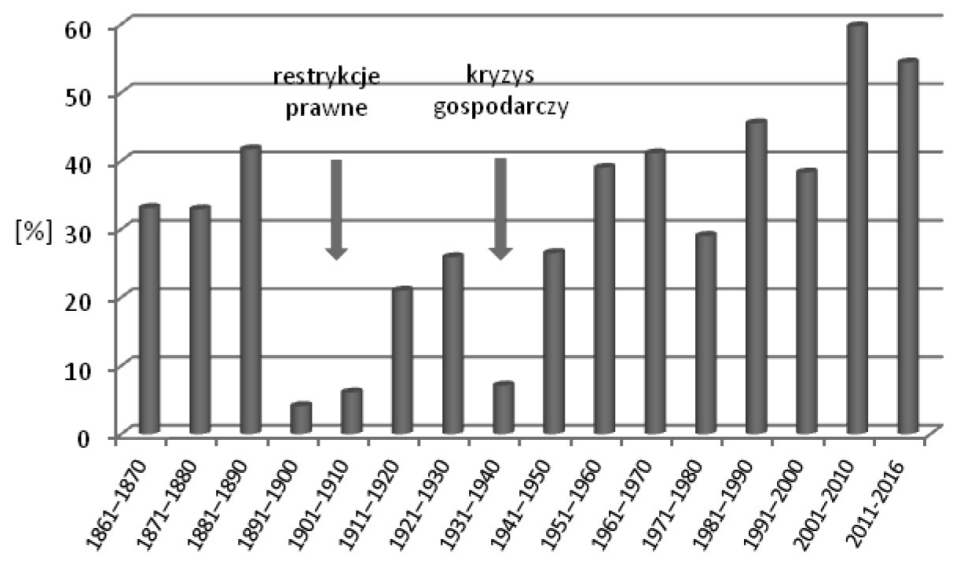

Rys. 2. Udział migracji zagranicznej netto w przyroście rzeczywistym w latach 1861-2016 Źródło: [Australian Historical... 2014; Australian Demographic... 2017].

- Znaczenie migracji w rozmiarach rozwoju ludności potwierdza wielkość składników przyrostu rzeczywistego. Chociaż przyrost naturalny jest także dodatni, to jednak udział salda migracji jest przeważający w wielkości przyrostu rzeczywistego (rys. 3).

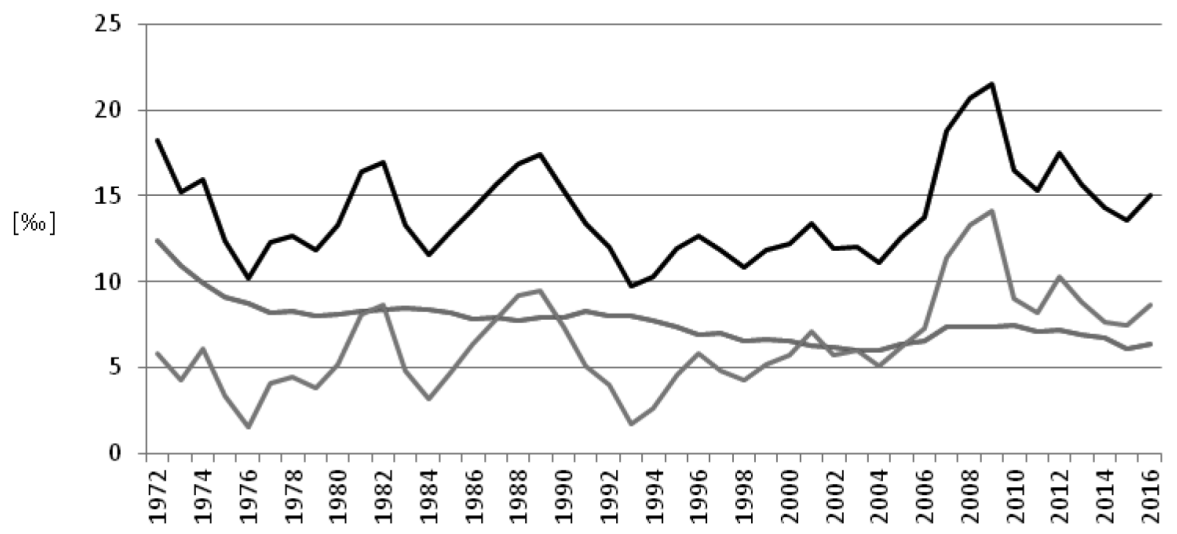

- przyrostnaturalny _ przyrostmigracyjny _ przyrostrzeczywisty

Rys. 3. Przyrost rzeczywisty i jego elementy składowe w Australii w latach 1972-2016

Źródło: [Australian Historical... 2014; Australian Demographic... 2017]. 
- Także bezwzględne wartości salda migracji potwierdzają jego znaczenie w rozwoju ludnościowym, w rozpatrywanym okresie ostatnich 14 lat saldo migracji wahało się od 100 do 300 tys. osób (rys. 4).

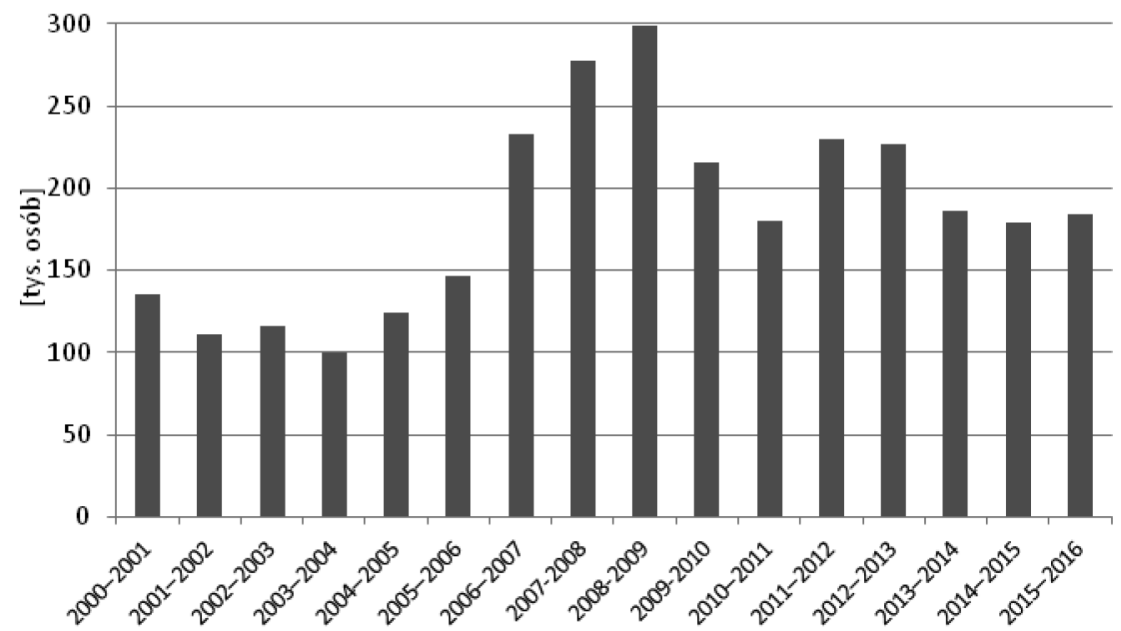

Rys. 4. Migracja zagraniczna netto w Australii w latach 2000-2016

Źródło: [Migration 2001-2017].

\section{Polityka ,białej Australii”" (White Australia) i polityka wielokulturowości}

Mówiąc o wielkości migracji do Australii, należy wspomnieć o różnych czynnikach wpływających na jej rozmiary. Niewątpliwie zaliczyć do nich należy odkrycie złóż złota w Australii i niekontrolowany napływ imigrantów w latach 50. XIX w. Pomiędzy 1851 a 1860 r. napłynęło do Australii pół miliona Chińczyków, co wywołało niezadowolenie mieszkańców Australii. Napływ z Azji taniej siły roboczej, która stanowiła konkurencję na rynku pracy dla pracowników z Europy (szczególnie Brytyjczyków), a także dbałość o czystość rasową ludności dało podstawy do wprowadzenia w życie surowych ograniczeń imigracyjnych.

W latach 80. XIX w. wszystkie kolonie ujednoliciły swoje prawo i uniemożliwiły Chińczykom emigrację do Australii, potem restrykcje migracyjne objęły wszystkich nie-Europejczyków. W 1901 r. powstał Związek Australijski i także w tym roku wydany został pierwszy akt federacyjny odnoszący się do polityki migracyjnej: Immigration Restriction Act, stanowiący formalne usankcjonowanie implementacji polityki „białej Australii”. Także w tym samym roku uchwalono Pacific Island Labourers Act służący stopniowemu (do 1906 r.) odsyłaniu migrantów pochodzących z Wysp Pacyfiku do ich krajów pochodzenia. Po II wojnie światowej powołano po 
raz pierwszy w historii Australii Departament Imigracji z ministrem Arthurem Calwellem na czele, wprowadzono Mass Migration Programm. W 1947 r. wprowadzono ułatwienia imigracyjne dla osób posiadających przydatne kwalifikacje, tzw. Assisted Passage Scheme, zainicjowano politykę łączenia rodzin (Operation Reunion).

W 1958 r. przyjęto Migration Act, nakazujący przymusowe zatrzymywanie każdej osoby, która nielegalnie dostała się na terytorium Australii. Zwolnienie nastąpić mogło dopiero po uzyskaniu przez tę osobę wizy. Lata 60. XX w. to liberalizacja polityki migracyjnej - chęć poprawy wizerunku Australii (jako partnera handlowego) postrzeganej jako kraj antyazjatycki. Innym powodem, który przyczynił się do zmiany prowadzonej polityki migracyjnej, był wpływ i naciski opinii publicznej w sprawie imigrantów wywołane m.in. wojną w Wietnamie.

Pierwszymi oznakami zmian w polityce migracyjnej było porzucenie (lata 1966-1973) zasady całkowitej asymilacji imigrantów ze społeczeństwem australijskim, umożliwiające im zachowanie odmiennej tożsamości, na którą składa się m.in. kultura i język kraju pochodzenia. Wprowadzenie pojęcia wielokulturowości w oficjalnej nomenklaturze Australii nastąpiło w 1973 r. Następnym etapem było zrównanie uprawnień obywateli krajów nieeuropejskich z uprawnieniami obywateli krajów europejskich pod względem okresu oczekiwania na możliwość złożenia wniosku o obywatelstwo australijskie (trzy lata po uzyskaniu statusu stałego rezydenta). Liberalizacja prawa w tym zakresie polegała także na całkowitym wyeliminowaniu z polityki imigracyjnej kryterium rasy. Ratyfikowano wszystkie umowy międzynarodowe (zarówno pomiędzy krajami, jak i z organizacjami międzynarodowymi) odnoszące się do kwestii imigracji i rasy. Wreszcie w 1975 r. przyjęto ustawę o dyskryminacji rasowej, w której uznano za niezgodną z prawem dyskryminację ze względu na rasę i pochodzenie etniczne. W kalendarium wprowadzania polityki wielokulturowości należy także odnotować powołanie Australijskiego Instytutu ds. Wielokulturowości (1979), co potwierdzało usankcjonowanie tejże polityki. Potwierdzenie polityki wielokulturowości zawarto w New Agenda for Multicultural Australia (1999), w którym podkreślano szacunek dla innych kultur, równość społeczną i korzyści płynące z różnorodności.

Polityka wielokulturowości ${ }^{1}$ opiera się na czterech zasadach, są to:

- poszanowanie dla odmienności kulturowej,

- zapewnienie równości każdej jednostce,

- wspieranie społecznej integracji,

- aktywny udział każdej jednostki w życiu społecznym.

Każdy imigrant ma prawo zachowywać swą tożsamość kulturową przez praktykowanie takiego stylu życia i zachowywanie takich tradycji, które wybiera i które

${ }^{1}$ Wdrożenie polityki wielokulturowości nie byłoby możliwe, gdyby nie prowadzone na tym polu badania wybitnych socjologów i ich współpraca w tym zakresie z Ministerstwem Imigracji. Za jednego z ojców wielokulturowości Australii uważany jest prof. Jerzy Zubrzycki, naukowiec pochodzenia polskiego. 
nie kolidują z australijskim prawem, systemem politycznym, a także podstawowymi wartościami. Nie jest to pełna swoboda ani pełny kulturowy pluralizm. Wielokulturowość daje wolność wystarczającą do zachowania etnicznych tożsamości, tradycji i stylów życia. Co ważniejsze, te rozmaite etnokulturowe style życia są nie tylko tolerowane, ale także traktowane jako pełnoprawne i pełnowartościowe. Mówiąc językiem potocznym, możesz być prawdziwym i dobrym Australijczykiem, nie będąc typowym Australijczykiem

Multikulturalizm nie oznacza zupełnej swobody, jeśli chodzi o prowadzenie polityki imigracyjnej. Australia prowadzi w dalszym ciągu wysoce selektywną politykę imigracyjną. Rząd australijski kontroluje bezpośrednio, m.in. poprzez system punktowy i kwoty ${ }^{2}$, imigrację na stałe, a pośrednio poprzez kryteria określone w prawie imigrację czasową. Są trzy ścieżki umożliwiające zamieszkanie w Australii na stałe (rys. 5).
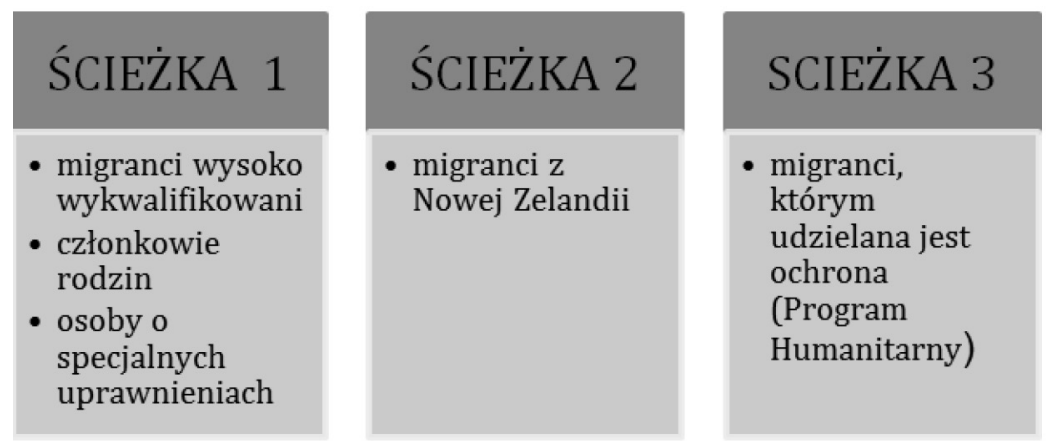

Rys. 5. Prawo do zamieszkania w Australii na stałe

Źródło: [Krakowiak 2012].

Po wprowadzeniu polityki wielokulturowości nie brakowało krytyków takich rozwiązań. Głosy te stawały się coraz liczniejsze, szczególnie wobec wzrastającego napływu boat people. Pierwsza duża fala uchodźców pojawiła się podczas kryzysu na Półwyspie Indochińskim, wtedy to przyjmowanie uchodźców uznawano za moralny obowiązek. Można powiedzieć, że kierunek polityki wobec uchodźców od końca lat 80. jest uzależniony od tego, jaka partia sprawuje władzę, czy jest to Partia Pracy, czy Partia Liberalna. Bowiem właśnie za rządów konserwatywnego premiera Johna Howarda (1996-2007) nastąpiło pewne odejście od zasad wielokulturowości. Wtedy to wprowadzono nowy system wizowy (wcześniej wizy bez limitu czasowe-

${ }^{2}$ Są ściśle określone roczne kwoty, np. w roku 2011 - migranci wysoko wykwalifikowani 113850 , członkowie rodzin - 54 550, osoby o specjalnych uprawnieniach (służba w wojsku australijskim przed 1981) - 300 miejsc. Przyjmowanie cudzoziemców w ramach Programu Humanitarnego limit roczny 13-14 tys. 
go) oraz utworzono ośrodki dla uchodźców na wyspach Nauru i Manus. Po dojściu do władzy Kevina Rutha (Partia Pracy) wprowadzono liberalizację wcześniejszych decyzji. Ponowne usztywnienie polityki nastąpiło pod rządami prawicowego premiera Tony'ego Abbotta. Abbott z ,zatrzymania łodzi” uczynił jedno z głównych zadań swojego rządu i jeszcze bardziej zaostrzył politykę.

Obecnie działa tak zwana operacja Sovereign Borders, która została rozpoczęta we wrześniu 2013 r. Do walki z imigrantami zaprzęgnięto wojsko, które jest głównym wykonawcą nowej polityki ,zero tolerancji”. Nadrzędnym celem jest zawracanie z drogi łodzi przemytników ludzi. Władze chcą uniknąć zatrzymywania imigrantów, którzy po zesłaniu do obozów stają się długotrwałym ,problemem”. Prowadzona jest też kampania informacyjna, głównie na Sri Lance oraz w Indonezji, gdzie za australijskie pieniądze lokalne władze mają przekonywać ludzi, iż nie ma sensu wybierać się w ryzykowną podróż do Australii, bowiem i tak nigdy nie uda się do niej dotrzeć. Równocześnie wspierana jest walka z gangami przemytników ludzi.

Wielokulturowość australijska przedstawiana jest jako wspólny mianownik zróżnicowanych stylów życia, przekonań i tożsamości. Mówiąc potocznie, jest to „multiculturalism for all Australians”, a nie strategia obronna świeżych imigrantów czy mniejszości. Pomimo stosunkowo długiej kariery (wielokulturowość australijska datuje się od 1977 r.), wielokulturowość jest często wypaczana, a przynajmniej błędnie interpretowana. Tak więc pluralizm wielokulturowy ma wyraźne granice - o czym często zapominają jego krytycy. Australijczyków obowiązuje jeden system prawny, jedna interpretacja sprawiedliwości, jeden wspólny system demokracji parlamentarnej, jedna „,nadrzędna” tożsamość narodowa i patriotyzm, jeden kodeks obowiązków społecznych i jeden język urzędowy. Stąd nacisk na przymiotnik ,,integracyjna”, który często towarzyszy słowu „wielokulturowość”. W australijskiej wielokulturowości integracyjnej nie ma miejsca na „pluralizm prawny” (np. elementy praw religijnych, takich jak szariat), nie ma tolerancji dla etnicznej segmentacji czy apartheidu, nie mówiąc o etnoterytorialnej autonomii. Wielokulturowość odrzuca wszelkie formy dyskryminacji, łącznie z dyskryminacją kobiet, nawet wtedy gdy taką dyskryminację przedstawia się jako ,święte i odwieczne tradycje”. Poligamia, przemoc, okrucieństwo (wobec ludzi i zwierząt) i wszelkie praktyki w sposób oczywisty szkodliwe dla zdrowia są odrzucane przez australijskie prawo i politykę wielokulturowości [Pakulski 2012].

Zdaniem Magdaleny Lesińskiej [2012], wśród argumentów wysuwanych przez sceptyków czy wręcz przeciwników polityki wielokulturowości jest wiele takich, które należy wziąć pod uwagę i rozważyć ich zasadność w kontekście polityk integracyjnych państw europejskich. Jeden z najpoważniejszych zarzutów dotyczy tego, że polityka wielokulturowości nie tylko nie dąży do zapewnienia spójności społecznej, która powinna być nadrzędnym celem zróżnicowanych kulturowo wspólnot, ale wręcz jest z nią sprzeczna poprzez podkreślanie tego, co wspólnotę dzieli, a nie co ją łączy. Przeciwnicy polityki wielokulturowości postrzegają ją również jako zagrożenie dla bezpieczeństwa społecznego i publicznego krajów przyjmujących. 
Ten zarzut podnoszony jest przede wszystkim w kontekście rosnącej populacji muzułmanów w Europie, zamkniętych we własnych religijnych wspólnotach i wyodrębnionych dzielnicach (co według niektórych jest bezpośrednim efektem polityki wielokulturowości), oraz łączony w prosty sposób z zagrożeniem terroryzmem. Bez wątpienia ton debaty na temat integracji imigrantów w Europie w ostatnim czasie uległ przemianie. Wiara, że polityka równouprawnienia czy wręcz promowania kultur grup napływowych przyniesie pozytywne efekty integracyjne i przyczyni się do powstania wspólnoty opartej na prawie, poszanowaniu inności i tolerancji, została zastąpiona przez poczucie zagrożenia, strach przed imigrantami i ogólne niezadowolenie.

Termin „multikulturalizm” uległ w Europie „semantycznemu rozciągnięciu” (jak to nazwał Sartori) - jego znaczenie rozmywa się w krytycznym dyskursie. Należy zatem przywrócić temu terminowi więcej precyzji, a pojęciu wielokulturowości - więcej użyteczności analitycznej. Być może powinniśmy sprecyzować te koncepcje jako ,wielokulturowość australijska” albo ,wielokulturowość integracyjna”. Dopiero w tak sprecyzowanej formie pojęcie wielokulturowości będzie można poddać bardziej precyzyjnej i politycznie neutralnej ocenie „użyteczności” [Pakulski 2012].

\section{Zakończenie}

Potencjał ludnościowy Związku Australijskiego ukształtował się w znacznej mierze w wyniku systematycznego dopływu imigrantów. Migracja stanowi obecnie istotniejszy niż przyrost naturalny czynnik wpływający na wzrost ludnościowy Australii. Przez blisko sto lat kraj ten prowadził „politykę białej Australii”, która obejmowała nie tylko stosunek państwa i Australijczyków do ludności tubylczej, ale także do imigrantów. Paradoksalnie ta, u zarania, kolonia zesłańców, a więc ludzi wyrzuconych na margines społeczny, przez całe dziesięciolecia broniła się przed napływem i marginalizowała wszelkie mniejszości etniczne i rasowe. Współczesna polityka Australii w kwestii migrantów zakłada współistnienie oraz różnorodność pod względem etniczno-kulturowym, zawodowym, ideologicznym, religijnym - multikulturalizm jest elementem rozwoju społecznego kraju.

Dyskusja nad wielokulturowością w Australii toczy się w dalszym ciągu, szczególne w kontekście uchodźców. Stawiane są pytania, czy istnienie społeczeństwa wielokulturowego przestanie implikować jakiekolwiek problemy. Czy będzie to w ogóle możliwe i czy stanie się to raczej w wyniku przyjętych rozwiązań, czy wskutek spontanicznie zachodzących w tym społeczeństwie procesów? To pytanie pozostaje otwarte. 


\section{Literatura}

Australian Demographic Statistics, 2017, ABS, Canberra.

Australian Historical Population Statistics, 2014 , No. 3105.0.65.001, ABS, Canberra.

Holzer J.Z., 2003, Demografia, PWE, Warszawa.

Janiszewska A., Klima E., 2009, Zarys geografii społeczno-ekonomicznej Australii, Wyd. UŁ, Łódź.

Kaczmarczyk P., Okólski M., 2008, Polityka migracyjna jako instrument promocji zatrudnienia i ograniczania bezrobocia, Ośrodek Badań nad Migracjami WNE UW, Warszawa

Krakowiak M., 2012, Droga do wielokulturowości - polityka migracyjna Australii, Biuletyn Migracyjny, nr 33, s. 5-8.

Lesińska M., 2012, Wielokulturowość w Europie. Quo vadis?, Biuletyn Migracyjny, nr 33, s. 11-12.

Migration, 2001-2017, No. 3412.0, ABS, Canberra.

Pakulski J., 2012, Australijski program wielokulturowości, Biuletyn Migracyjny, nr 33, s. 9-11.

Sale C., Wilson G., 1984, Australia our Changing Land, Longman Cheshire. 